\title{
Determinants of Liquidity of Listed Enterprises: Evidence from Vietnam*
}

\author{
Hang Thu DANG ${ }^{1}$
}

Received: August 01, 2020 Revised: September 20, 2020 Accepted: October 05, 2020

\begin{abstract}
The paper examines the influence of internal factors and external factors on liquidity of Vietnamese listed enterprises. The study uses robust regression techniques in the fixed effects linear panel data using data collected from companies listing on the stock market in Vietnam during 2008-2019, with a total of 6,700 observations. Liquidity of Vietnamese listed enterprises is measured by current assets to current liabilities, whereas firm size, capital adequacy, profitability, leverage are used as internal determinants. Further, economic activity, inflation rate, exchange rate, and interest rate are the external factors which are considered. The research results indicate that capital adequacy, return on equity, leverage, economic activity have a positive effect on firm's liquidity, whereas return on assets and exchange rate have a negative effect on firm's liquidity and firm size, inflation rate and lending rate have no correlation with firm's liquidity. Based on the research results, the author suggests that the firms should have optimum current ratio by balancing the current assets and current liabilities in order to avoid a situation of high liquidity or low liquidity. This research seeks to bridge a gap which is present in the body of literature on listed enterprise's liquidity in Vietnam. The findings may be useful for financial managers, investors, and financial management consultants.
\end{abstract}

Keywords: Liquidity, Internal and External Determinants, Vietnam

JEL Classification Code: C22, G11, G32

\section{Introduction}

Liquidity is an important issue in financial decision making. It includes investment in asset that requires appropriate financing investment. However, liquidity issues are usually neglected by the firms in financial decision making as it involves investment and financing in the shortterm period. If the firm doesn't have enough liquid funds to pay its bills and suppliers, the situation could quickly deteriorate to the point of bankruptcy. Due to the presence of market frictions, there is generally a considerable variation observed in the liquidity ratios among different types of firms according to the size of the industry and degree of financial leverage.

\footnotetext{
*Acknowledgements:

The author is thankful to University of Transport Technology for funding this research. I would like to thank the anonymous referees for their helpful comments and suggestions.

${ }^{1}$ First Author and Corresponding Author. Faculty of Transport Economics, University of Transport Technology, Vietnam [Postal Address: 54 Trieu Khuc Street, Thanh Xuan District, Hanoi, 100000, Vietnam] Email: hangdt@utt.edu.vn

(c) Copyright: The Author(s)

This is an Open Access article distributed under the terms of the Creative Commons Attribution Non-Commercial License (https://creativecommons.org/licenses/by-nc/4.0/) which permits unrestricted non-commercial use, distribution, and reproduction in any medium, provided the original work is properly cited.
}

Listed companies have the basic characteristics of different shareholders, which forms the company's ownership structure that is ownership of the equity capital, ownership of solvency and liquidity. The study of the determinants of liquidity of listed companies is a necessary research topic. There have been a number of studies conducted such as Opler et al. (1999) in USA, Lyroudi and Lazaridis (2000) in UK, Ferreira and Vilela (2004) in EMU countries, Bruinshoofd and Kool (2004) in Netherlands, Isshaq and Bokpin (2009) in Canada, Velmurugan and Annalakshmi (2015) in India, Al-Homaidi, Tabash, AlAhdal, Farhan \& Khan (2020) in India. These findings are mostly established in developed countries with a significant economic gap comparing to Vietnam.

Thus, the present study aims to examine the determinants of liquidity of Vietnamese listed firms over a time period from 2008 to 2019. In the process, it will empirically investigate both internal and external determinants that affect the listed firms' liquidity in Vietnam. The present study seeks to fill the existing gap by empirically analyzing firms specifics variables such as firm size (FSIZE), capital adequacy (CAD), profitability (ROA, ROE), leverage (LEV), and macroeconomic determinants such as (economic activity (GDP), inflation rate (IFR), exchange rate $(\mathrm{EXCH})$, and interest rate (IR). 
The study is organized in the following manner. Section two presents the relevant literature review and hypotheses of the study. Section three explains the data and methodology used in the study. Section four shows the results of empirical analysis and discussion. The last section includes conclusions and recommendations of the study.

\section{Literature Review and Hypotheses}

According to Bhunia and Das (2012), Liquidity is the capacity of a firm to meet their present liabilities as they fall due. Over the top measures of current resources claimed by a firm would perhaps expand the odds of inside subsidizing which brings about a connection between influence and liquidity. Many studies examining the determinants of liquidity have been done in listed enterprises, especially in a particular industry such as banking, insurance, manufacturing, and real estate industries. The findings indicate that there are different categories that these determinants can be classified into: internal factors such as firm size, capital adequacy, profitability, leverage, deposits, non-interest income, firm age etc. and external factor such as economic activity, inflation rate, exchange rate, and interest rate.

To find the effect of internal factors on the liquidity of listed firms, Smith and Begemann (1997) in their study have observed that liquidity is associated with return on investment. Opler et al. (1999) examined the determinants and implications of holdings of cash and marketable securities by publicly traded U.S. firms in the 1971-1994 period. The empirical studies have shown that the liquidity was inversely correlated with the firm size, working capital, leverage, and dividend. On the other hand, the cash flow/assets ratio, capital expenditure/total assets ratio, industry risk, and R\&D expense/revenue ratio are positively correlated with liquidity. The authors concluded that large firms have the greatest access to the capital tend to hold less cash, resulting in less liquidity. Lyroudi and Lazaridis (2000) showed that there is a strong positive association between CCC and ROA. The results also revealed that there is a significant and positive association between CCC and current ratio and liquid ratio.

Ferreira and Vilela (2004) studied the determinants of liquidity in EMU countries including Germany, Austria, France, Greece, Italy, the Netherlands, Portugal, Spain, Belgium, Ireland, Finland and Luxemburg during the 19872000 period. The authors showed that liquidity is affected in the same direction as of investment opportunities and cash flow of businesses. Meanwhile, leverage, firm size and debt have a negative impact on liquidity. According to Velmurugan and Annalakshmi (2015), liquidity position of Indian tractor companies depends on size, return on investment, inventory turnover ratio, growth in sales, leverage and assets turnover ratio. Isshaq and Bokpin (2009) examined corporate liquidity management of companies listed on the Ghana Stock
Exchange (GSE) with the aim of ascertaining the determinants of corporate liquidity holdings. The results showed that liquidity is significantly influenced by a target liquidity level, size of the firm, return on assets and net working capital. Bagchi and Chakrabarti (2014) revealed a powerful adverse correlation between liquidity leadership and performance of companies, but company size has a beneficial connection to profitability of companies. Sumani and Roziq (2020) indicate that corporate governance has a significant negative effect on corporate liquidity policy. Tahir, Sadique, Syed, Rehman \& Ullah (2020) reveal that improvement in corporate governance mechanism would also develop the liquidity of the firm as measured by the current ratio.

In addition to the studies as mentioned above, there are many other factors which affect liquidity. There have also been several studies which uses liquidity as an important factor which has an effect on the profitability of the firms. Hamidah and Muhammad (2018) showed that the liquidity has significant relationship and impact on the company performance, this result is supported by the previous studies by Lee, Bach \& Baik (2011) who have stated that the liquidity has a significant impact on firm performance. Ismail (2016) revelated that current liquidity has a significant and positive influence on firms' financial performance (ROA). This result is consistent to the study of Lyroudi and Lazaridis (2000), Owolabi and Obida (2012), is contrary to the study of Eljelly (2004), Wang (2002), and Bagchi (2013).

To study the effect of external factors on the liquidity of listed firms, Al-Homaidi, Tabash, Farhan and Almaqtari (2019) showed that only GDP has a significant effect on liquidity, while inflation rate, interest rate, and exchange rate have an insignificant impact on liquidity. The coefficient of GDP, inflation rate, and interest rate have a positive impact on liquidity, while exchange rate has a statistically negative influence on liquidity. Al-Homaidi, Tabash, Al-Ahdal, Farhan \& Khan (2020) studied the determinants of liquidity of 2154 listed firms in India. Liquidity (LQD) of Indian firms is measured by liquid assets to total assets, whereas bank size, capital adequacy, profitability, leverage, and firm age are used as internal determinants. Further, economic activity, inflation rate, exchange rate, and interest rate are the external factors which is taken into consideration. The authors show that the outcomes indicated that GDP, inflation rate, exchange rate and rate of interest statistically make a significant impact on liquidity of the firms in (pooled, fixed and random) effect models.

The study aims to examine the determinants of liquidity of Vietnamese listed firms over the time period from 2008 to 2019. In the process, it will empirically investigate both internal and external determinants that affect the listed firms' liquidity in Vietnam. Based on the statement above, the study has generated the following hypotheses for further verification. 
H1: Firm size is positively related to the liquidity of the listed firm

H2: Capital adequacy is positively related to the liquidity of the listed firm

H3: Profitability is positively related to the liquidity of the listed firm

H4: The leverage ratio is positively related to the liquidity of the listed firm

H5: The economic activity is negatively related to the liquidity of the listed firm

H6: The inflation rate is positively related to the liquidity of the listed firm

H7: The exchange rate is negatively related to the liquidity of the listed firm

H8: The interest rate is negatively related to the liquidity of the listed firm

\section{Model and Research Method}

\subsection{Research model}

Based on the review of previous scholars, a model has been advanced to examine the factors that may affect listed firms' liquidity in Vietnam as follows:

$$
\begin{aligned}
\mathrm{LQD}_{\mathrm{it}}= & \alpha_{\mathrm{i}}+\beta_{1} \mathrm{FSIZE}_{\text {it }}+\beta_{2} \mathrm{CAD}_{\mathrm{it}}+\beta_{3} \mathrm{PROF}_{\mathrm{it}}+\beta_{4} \mathrm{LEV}_{\text {it }} \\
& +\beta_{5} \mathrm{GDP}_{\mathrm{it}}+\beta_{6} \mathrm{IFR}_{\mathrm{it}}+\beta_{7} \mathrm{EXCH}_{\mathrm{it}}+\beta_{8} \mathrm{R}_{\mathrm{it}}+\varepsilon_{\mathrm{i}}
\end{aligned}
$$

In which, $\mathrm{LQD}_{\mathrm{it}}$ is the accumulated liquidity of firm $\mathrm{i}$ in year $t$, calculated by current asset/current liabilities and nine independent variables have been categorized into internal factors (firm size, capital adequacy, profitability, leverage ratio) and external factors (economic activity (GDP), inflation rate, exchange rate, and interest rate) as shown in Figure 1.

$\alpha_{i}$ is a constant term; $\mathrm{i}=1, ., \mathrm{N}$ and $\mathrm{t}=1, ., \mathrm{T}$. all other determinants are as explained in Table 1.

Firm size

Capital adequency

Profitability

Leverage ratio

Economic activity

Interest rate

External factors

Exchange rate

Inflation rate

Figure 1: Effects of internal and external factors on liquidity firms

Table 1: Describe the variable in the research model

\begin{tabular}{|l|c|l|c|}
\hline Variables & Codes & \multicolumn{1}{|c|}{ Measurement } & Impact direction \\
\hline Liquidity & LQD & Current asset/current liabilities & \\
\hline Firm size & FSIZE & Natural logarithm of total assets & + \\
\hline Capital adequacy & CAD & Equity to total assets & + \\
\hline Profitability & ROA & $\begin{array}{l}\text { Net profit to total assets } \\
\text { Net profit to total equity }\end{array}$ & + \\
\hline Leverage & ROE & Debt to equity ratio & - \\
\hline Economic Activity & GDP & Annual real GDP rate & - \\
\hline Interest rate & IR & Lending interest & - \\
\hline Exchange rate & EXCH & Average exchange rate in a year & + \\
\hline Inflation rate & IFR & Annual inflation rate & + \\
\hline
\end{tabular}




\subsection{Research Data}

Researching the determinants of liquidity of Vietnamese listed firms over a time period from 2008 to 2019 with 6,700 observations. The data of these companies is collected from their financial statements and the data set from Vietstock, as well as aggregated from the data published on some reputable securities websites such as cafef.vn or cophieu68.com. The original data will be aggregated and recalculated in the correct way of identifying variables, in which some variables will be regressed to get the remainder and initialize the corresponding new variable through Stata 15.0 .

\subsection{Data Processing Methods}

The study uses the Fixed Effect and Random Effect regression methods to estimate the impact of internal factors and external factors on the liquidity of listed companies in Vietnam. The research paper will use Hausman tests to examine which models of Fixed Effect and Random Effect give better estimates. In case the model has a defect, the author will use the Robust Standard errors method to overcome the defects.

\section{Research Results and Discussions}

\subsection{Descriptive Statistics}

Table 2 shows that the liquidity ratio shows the minimum value of 0.05784 , while the maximum value is 362.34 , and the mean value is 2.8897 , (S.D is 8.4995). The average value of the firm size is 11.7698 , the lowest is 9.1870 and the highest is 14.6061 . The average value of capital adequacy is 0.4966 , of which the lowest is -1.0306 and the highest is 0.9980 . The mean value of return on assets, return on equity and leverage ratio are $0.1115,0.0618$ and 1.7361 . The variable economic activity has an average value of $5.26 \mathrm{e}+11$, with a standard deviation of $1.52 \mathrm{e}+11$. The inflation rate has the largest value of 23.1154 , the smallest value is 0.6312 . The average value of the variable is 7.5537 with the standard deviation of 6.5291 . The exchange rate between 16,302 and 23,050 . The average value of lending rate is 2.5952 , the lowest is 1.925 and the highest is 2.2341 (See Table 2).

\subsection{Correlation Analysis}

The following Table 3 shows the correlation coefficients between variables. The purpose is to examine whether there is a close correlation between independent variables and dependent variables to exclude variable that may lead to multi-collinearity. Table 3 shows that firm size, leverage ratio, return on equity, lending rate have a negative relationship with liquidity ratio, while capital adequacy, return on assets, economic activity, exchange rate, and inflation rate have a positive association with firms' liquidity. The results show that the correlation coefficient between any pair of independent variables in the model is no less than 0.8 and therefore multicollinearity is unlikely to occur. To analyze more carefully, this study used the variance inflation factor (VIF) to test multicollinearity issues. The findings revealed that the variance inflation factor (VIF) values for all independent variables do not exceed 10.00 which suggest that there is no multicollinearity between variables (see Table 4).

\subsection{Empirical Results}

The empirical results of factors affecting firm's liquidity in listed enterprises are shown in Table 4.

Table 2: Statistical description of the sample for the year $2008-2019$

\begin{tabular}{|l|c|c|c|c|c|}
\hline Variables & Obs & Mean & Std. Dev. & Min & Max \\
\hline LQD & 6,707 & 2.8897 & 8.4995 & 0.05784 & 362.34 \\
\hline FSIZE & 6,707 & 11.7698 & 0.6630 & 9.1870 & 14.6061 \\
\hline CAD & 6,707 & 0.4966 & 0.2272 & -1.0306 & 0.9980 \\
\hline ROE & 6,700 & 0.1115 & 0.5544 & -40.82061 & 4.3462 \\
\hline ROA & 6,700 & 0.0618 & 0.0884 & -1.6932 & 0.7836 \\
\hline LEV & 6,700 & 1.7361 & 3.0577 & -16.1436 & 140.0325 \\
\hline GDP & 6,708 & $5.26 \mathrm{e}+11$ & $1.52 \mathrm{e}+11$ & $3.24 \mathrm{e}+11$ & $8.08 \mathrm{e}+11$ \\
\hline IFR & 6,708 & 7.5537 & 6.5291 & 0.6312 & 23.1154 \\
\hline EXCH & 6,708 & $20,587.86$ & 2072.122 & $16,302.25$ & $23,050.24$ \\
\hline IR & 6,708 & 2.5952 & 0.4319 & 1.925 & 3.2341 \\
\hline
\end{tabular}


Table 3: Results of correlation between key variables

\begin{tabular}{|c|c|c|c|c|c|c|c|c|c|c|}
\hline Variables & LQD & FSIZE & CAD & ROE & ROA & LEV & GDP & IFR & EXCH & IR \\
\hline LQD & 1 & & & & & & & & & \\
\hline FSIZE & -0.0873 & 1 & & & & & & & & \\
\hline CAD & 0.3127 & -0.3213 & 1 & & & & & & & \\
\hline ROE & -0.0084 & -0.0083 & 0.0489 & 1 & & & & & & \\
\hline ROA & 0.0109 & -0.0741 & 0.3549 & 0.2947 & 1 & & & & & \\
\hline LEV & -0.0994 & 0.1696 & -0.5241 & -0.5791 & -0.2143 & 1 & & & & \\
\hline GDP & 0.0242 & 0.1949 & 0.0482 & -0.0582 & -0.0983 & -0.0142 & 1 & & & \\
\hline IFR & 0.0029 & -0.1591 & -0.0348 & 0.0291 & 0.0377 & 0.0266 & -0.6890 & 1 & & \\
\hline $\mathrm{EXCH}$ & 0.0060 & 0.2032 & 0.0391 & -0.0604 & -0.1115 & -0.0239 & 0.8850 & -0.6828 & 1 & \\
\hline IR & -0.0014 & -0.0361 & -0.0196 & -0.0299 & -0.0783 & 0.0155 & -0.1029 & 0.4345 & 0.0002 & 1 \\
\hline
\end{tabular}

Table 4: Regression results of panel regression analysis

\begin{tabular}{|c|c|c|c|c|}
\hline \multirow{2}{*}{ Variables } & \multirow{2}{*}{ VIF } & \multicolumn{3}{|c|}{ Regression coefficients } \\
\hline & & FEM & REM & Robust FEM \\
\hline FSIZE & 1.19 & -0.826 & 0.237 & -0.826 \\
\hline CAD & 2.30 & $18.90^{* * *}$ & $17.47^{* \star *}$ & $18.90^{* * *}$ \\
\hline ROE & 2.02 & $1.202^{* * *}$ & $1.396^{* * *}$ & $1.202^{* *}$ \\
\hline ROA & 1.37 & $-8.454^{* * *}$ & $-11.33^{* * *}$ & $-8.454^{* * *}$ \\
\hline LEV & 2.55 & $0.346^{* * *}$ & $0.396^{* * *}$ & $0.346^{* * *}$ \\
\hline GDP & 4.99 & $3.66 \mathrm{e}-12^{* * *}$ & $3.44 \mathrm{e}-12^{* * *}$ & $3.66 \mathrm{e}-12^{*}$ \\
\hline IFR & 2.97 & 0.0333 & 0.0335 & 0.0333 \\
\hline $\mathrm{EXCH}$ & 5.63 & $-0.000177^{*}$ & $-0.000235^{\star *}$ & $-0.000177^{*}$ \\
\hline IR & 1.57 & -0.0917 & -0.101 & -0.0917 \\
\hline Cons & & 4.729 & $-5.685^{*}$ & 4.729 \\
\hline $\mathrm{N}$ & & 6700 & 6700 & 6700 \\
\hline R-sq & & 0.071 & 0.069 & 0.071 \\
\hline Prob (F-statistic) & & 0.0000 & 0.0000 & 0.0000 \\
\hline Hausman test & & \multicolumn{2}{|c|}{$\begin{array}{cc}\text { chi2 } 2(7)= & 40.40 \\
\text { Prob }>\text { chi2 }= & 0.0000\end{array}$} & \\
\hline Modified Wald test & & \multicolumn{2}{|c|}{$\begin{array}{lr}\text { chi } 2(559)= & 3.8 \mathrm{e}+07 \\
\text { Prob }>\text { chi } 2= & 0.0000\end{array}$} & \\
\hline Wooldridge test & & \multicolumn{2}{|c|}{ 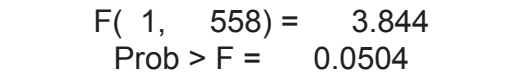 } & \\
\hline
\end{tabular}

Note: $\left({ }^{*}\right),\left({ }^{* *}\right),\left({ }^{* * *}\right)$ represent for the significant level at $1 \%, 5 \%$ and $10 \%$, respectively. 
The Hausman test was adopted to select the suitable model estimation between fixed model and random model effect. The p-value results indicate that the fixed-effect model is suitable as the random-effect model because the Hausman $\mathrm{p}$-value test is less than $0.05(\mathrm{p}=0.00<0.05)$. The Wooldridge test indicates that the model has no autocorrelation (p-value $=0.0504>0.05)$. Furthermore, the Modified Wald test indicates that the model has heterogeneity ( $\mathrm{p}$-value $=0.0000$ $<0.05$ ) and the author proceeds to overcome the discovered defects of the model by Robust Standard errors method.

The results in Table 4 show that firm size, inflation rate and lending rate has no correlation with firm's liquidity. The results of this research are similar to the research of Chen and Mahajan (2010), and contrary to the research of Opler et al. (1999), Isshaq and Bokpin (2009), Gill and Mathur (2011), Al Homaidi et al (2020).

The variable capital adequacy has a positive correlation with firm's liquidity. This supports the authors' expectations, with a coefficient of 18.90 and statistical significance at $10 \%$. This result is consistent with the result of Isshaq and Bokpin (2009) and contrary to the research of Al Homaidi et al (2020).

With the results just mentioned from the regression, the return on assets has a negative correlation with the firm's liquidity with statistical significance. The value of regression coefficient that a unit increase in return on assets shall decrease liquidity by 8.454 units. Increase in return on assets leads to decrease in liquidity. The return on equity has a positive correlation with the firm's liquidity with statistical significance, which means that the better the profitability, the higher the liquidity of the business. This result is consistent with the research of Velmurugan and Annalakshmi (2015), Isshaq and Bokpin (2009), Al Homaidi et al (2020).

The regression coefficient indicates that the leverage positively influences the liquidity. The value of regression coefficient that a unit increase in leverage shall increase liquidity by 0.346 units. Increase in leverage ratio leads to increase in liquidity. This result is similar with the research of Opler et al. (1999), Al Homaidi et al (2020) and contrary to the research of Ferreira and Vilela (2004).

The outcomes indicated that the exchange rate has a negative correlation with firm's liquidity. Low exchange rate may have high liquidity. The regression coefficient indicates that GDP positively influences the liquidity. Supported by Al-homaidi et al (2020) who found that GDP has a significant impact on liquidity.

\section{Conclusion and Recommendations}

This research uses a sample of 6,700 observations from companies listed on Vietnam's stock market in the period of 2008-2019 to examine the effects of general internal factors (firm size, capital adequacy, profitability, leverage ratio) and external factors (economic activity (GDP), inflation rate, exchange rate, and interest rate to firm's liquidity.

The findings reveal that capital adequacy, return on assets, return on equity, leverage ratio, economic activity and exchange rate have statistically significant relationship with liquidity and firm size, inflation rate and lending rate has no correlation with firm's liquidity. Based on the research results, the authors propose the following policy implications:

The firms should have optimum current ratio by balancing the current assets and current liabilities in order to avoid over and under liquidity.

Maintaining excess liquidity may affect recycling of funds and will directly affect the profitability of the firms. At the same time low level of liquidity will lead to distress for companies in repaying their dues in time, which affects the reputation of the company. Thus, companies need to maintain an optimum level of liquidity which assists them to increase their profitability and their reputation.

This research aims to fill a current gap in the literature related to listed companies, it offers fresh empirical evidence using distinct statistical instruments. However, in the future it is necessary to consider the liquidity of the business on other indicators for a more general assessment, such as quick ratio.

Finally, this research provides helpful ideas and empirical evidence on the internal and external determinants of the Vietnam listed enterprises is very useful to financial managers, investors, and financial management consultants.

\section{References}

Al-homaidi, E. A., Tabash, M. I., Farhan, N. H., \& Almaqtari, F. A. (2019). The determinants of liquidity of Indian listed commercial banks: A panel data approach. Cogent Economics \& Finance, 7(1), 1-20. https://doi.org/10.1080/23322039.2019. 1616521 .

Al-Homaidi, E. A., Tabash, M. L., Al-Ahdal, W. M., Farhan, N. H., \& Khan, S. H. (2020). The Liquidity of Indian Firms: Empirical Evidence of 2154 Firms. Journal of Asian Finance, Economics, and Business, 7(1), 19-27. https://doi.org/10.13106/jafeb.2020. vol7.no1.19

Bagchi, B. (2013). Liquidity-profitability relationship: Empirical evidence from Indian fast moving consumer goods firms. International Journal of Applied Management Science, 5(4), 355-376. https://doi.org/10.1504/IJAMS.2013.057109.

Bagchi, B., \& Chakrabarti, J. (2014). Modeling liquidity management for Indian FMCG firms. International Journal of Commerce and Management, 24(4), 334-354. https://doi. org/10.1108/IJCoMA-10-2012-0065.

Bhunia, A., \& Das, A. (2012). Affiliation between working capital management and profitability. Interdisciplinary journal of contemporary research in business, 3(9), 957-968. 
Bruinshoofd, W. A., \& Kool, C. J. (2004). Dutch corporate liquidity management: New evidence on aggregation. Journal of Applied Economics, 7(2), 195-230. https://doi.org/10.1080/15140326. 2004.12040609.

Chen, N., \& Mahajan, A. (2010). Effects of macroeconomic conditions on corporate liquidity: International evidence. International Research Journal of Finance and Economics, 35(35), 112-129.

Eljelly, A. M. A. (2004). Liquidity-profitability tradeoff: An empirical investigation in an emerging market. International Journal of Commerce and Management, 14(2), 48-61.

Ferreira, M. A., \& Vilela, A. S. (2004). Why do firms hold cash? Evidence from EMU countries. European Financial Management, 10(2), 295-319. https://doi.org/10.1111/j.13547798.2004.00251.x.

Gill, A., \& Mathur, N. (2011). Factors that influence corporate liquidity holdings in Canada. Journal of Applied Finance and Banking, 1(2), 1-7.

Hamidah, R., \& Muhammad, K. H. B. N. (2018). The effect leverage, liquidity and profitability on the companies performance in Malaysia. Journal of Humanities, Language, Culture and Business, 2(7), 9-15

Ismail, R. (2016). Impact of liquidity management on profitability of Pakistani firms: A case of KSE-100 Index. International Journal of Innovation and Applied Studies, 14(2), 304-314.

Isshaq, Z., \& Bokpin, G. A. (2009). Corporate liquidity management of listed firms in Ghana. Asia-Pacific Journal of Business Administration. https://doi.org/10.1108/17574320910989122.

Lee, S. H., Bach, S. B., \& Baik, Y. S. (2011). The impact of IPOs on the values of directly competing incumbents. Strategic Entrepreneurship Journal, 5(2), 158-177.
Lyroudi, K., \& Lazaridis, Y. (2000). The cash conversion cycle and liquidity analysis of the food industry in Greece. SSRN Electronic Journal. http://dx.doi.org/10.2139/ssrn.236175

Opler, T., Pinkowitz, L., Stulz, R., \& Williamson, R. (1999). The determinants and implications of corporate cash holdings. Journal of Financial Economics, 52(1), 3-46. https:// doi.org/10.1016/S0304-405X(99)00003-3.

Owolabi, S. A., \& Obida, S. S. (2012). Liquidity management and corporate profitability: Case study of selected manufacturing companies listed on the Nigerian stock exchange. Business Management Dynamics, 2(2), 10-25.

Smith, M. B., \& Begemann, E. (1997). Measuring associations between working capital and return on investment. South African Journal of Business Management, 28(1), 1-5. http:// dx.doi.org/10.4102/sajbm.v28i1.783.

Sumani, S., \& Roziq, A. (2020). Reciprocal Capital Structure and Liquidity Policy: Implementation of Corporate Governance toward Corporate Performance. Journal of Asian Finance, Economics and Business, 7(9), 85-93. https://doi.org/10.13106/ jafeb.2020.vol7.no9.085

Tahir, S. H., Sadique, M. A. B., Syed, N., Rehman, F., \& Ullah, M. R. (2020). Mediating Role of Liquidity Policy on the Corporate Governance-Performance Link: Evidence from Pakistan. Journal of Asian Finance, Economics and Business, 7(8), 15-23. https://doi.org/10.13106/jafeb.2020.vol7.no8.015

Velmurugan, R., \& Annalakshmi, S. (2015). Determinants of liquidity of the select Indian tractor companies. Global Journal for Research Analysis, 4(4), 59-61. https://www.doi. org/10.36106/gjra.

Wang, Y. (2002). Liquidity management, operating performance, and corporate value: Evidence from Japan and Taiwan. Journal of Multinational Financial Management, 12(2), 159-169. 